\title{
Growth and Fruit Yield of Tomato (Solanum lycopersicum L.) under Different Levels of Phosphorus Fertilization
}

\section{${ }^{*}$ 1KAREEM, I; ${ }^{1}$ AZEEZ, R; ${ }^{2}$ KAREEM, SA; ${ }^{3}$ OLADOSU, Y; ${ }^{4}$ ABDULMALIQ, SY; ${ }^{1}$ EIFEDIYI, EK; ${ }^{1}$ ALASINRIN, SY; ${ }^{5}$ OLALEKAN, KK}

\author{
${ }^{* 1}$ Department of Agronomy, University of Ilorin, Ilorin, Nigeria \\ ${ }^{2}$ Department of Biology, School of Secondary Education (Science Programme), Federal College of Education (Special), Oyo, Nigeria. \\ ${ }^{3}$ Institute of Tropical Agriculture, Universiti Putra Malaysia, 43400 Serdang, Selangor, Malaysia \\ ${ }^{4}$ Department of Crop Production, Ibrahim Badamasi Babangida University, Lapai, Niger State, Nigeria. \\ ${ }^{5}$ Department of Agronomy, College Of Agriculture, Osun State University, P.M.B 4944, Osogbo, Osun State, Nigeria \\ *Corresponding Author Email: abdulkareemishaaq@gmail.com;Tel: +2348032454636
}

\begin{abstract}
Having substantial and working knowledge on phosphorus fertilization is a pre-requisite to profitable tomato production. Thus, the present research was conducted to determine the optimum phosphorus $(\mathrm{P})$ fertilizer rate for better fruit yield of tomato in Ilorin, a location in the Southern Guinea savannah zone of Nigeria. Five levels of phosphorus $(0,30,60,90 \mathrm{and} 120 \mathrm{kgP} / \mathrm{ha})$ were tested on UC82B tomato variety. The experiment was laid out in a randomized complete block design with 3 replications. Data were collected on plant height, number of leaves, leaf area and number of branches at different growth stages while data on fruit yield as well as its components were collected at harvest. Results showed that application of $30 \mathrm{kgP} /$ ha produced plants with the highest leaf area The control and $30 \mathrm{kgP} /$ ha produced the highest number of leaves. Application of $90 \mathrm{kgP} / \mathrm{ha}$ and $120 \mathrm{kgP} / \mathrm{ha}$ resulted in production of highest number of fruits while application of $90 \mathrm{kgP} / \mathrm{ha}$ alone resulted in production of the tallest plants, highest number of branches and highest fruit yield. The yield was $66 \%$ better than the control. It was, therefore, concluded that $90 \mathrm{kgP} /$ ha should be used for optimum tomato fruit production in the agro-ecological zone of the research and places with the same climatic and edaphic conditions.
\end{abstract}

DOI: https://dx.doi.org/10.4314/jasem.v24i3.16

Copyright: Copyright (C) 2020 Kareem et al. This is an open access article distributed under the Creative Commons Attribution License (CCL) which permits unrestricted use, distribution and reproduction in any medium provided the original work is properly cited.

Dates: Received: 16 November 2019; Revised: 11 January 2020; Accepted: 22 February 2020

Keywords: Phosphorus fertilization, tomato, growth improvement and fruit yield

Tomato (Solanum lycopersicum L) belongs to the family Solanaceae. It is a widely grown vegetable in the world because it is recognized as a rich source of vitamins and minerals. Consumption of tomato can prevent several diseases (Willcox et al., 2003) because it has anti-oxidants like carotene, phenolic compounds and ascorbic acid (Periago et al., 2009). Availability of tomato and other crops at all times cannot be attained without availability of essential plant nutrients (Chen, 2006; Ali et al., 2008). Therefore, plant nutrients become essential components of sustainable agriculture. In the same vein, the essential nutrients must be readily available in sufficient and balanced quantities for optimum plant growth and yield. Nevertheless, suitable and balanced combinations of macro and micro nutrients should be considered not only for essentiality of crop growth and yield but also for friendliness of our environment (Chen, 2006). Crops can grow in a wide range of environments by adjusting their morphological and physiological characteristics to environmental conditions (Lambers et al. 1990). Phosphorus (P) is an example of nutrient elements that may differ in availability in different environments. This nutrient element often limits plant growth (Schachtman et al., 1998) especially in heavily leached soils (Raaimakers et al. 1995). Adequate phosphorus nutrition enhances many aspects of plant physiology including the fundamental processes of photosynthesis, nitrogen fixation, flowering, fruiting (including seed production) and maturation. A mineral element that has been reported to be important for fruit growth and development is phosphorus (P). Studies by the International Institute of Tropical Agriculture (IITA), Ibadan, Nigeria from 1989 to 1998 showed that phosphorus deficiency is a major yield-limiting factor in several locations in Nigeria. This results from low organic matter content and high P-fixation capacity of the soils (Mokwunye, 1999). As for tomato, Aduayi et al. (2002) made it clear that $\mathrm{P}$ is the mineral nutrient needed in largest quantity in Nigeria by tomato plant compared to other macronutrients. In the same vein, 
it has been established that when there is optimum $\mathrm{P}$, much of energy required for plant metabolism which is stored chemically in the form of complex organic phosphates and adenosine triphosphate (ATP) will be made available and released as required. Therefore, important chemical processes involved in growth will be driven steadily. Despite the fact that phosphorus encourages root development and provides energy by forming ATP (Shaheen et al., 2007), there is dearth of research on influence of phosphorus nutrition on tomato growth and fruit yield in the Southern Guinea savannah zone of Nigeria. Also, the use of blanket recommendation in fertilizer application which is usually the order of the day among the farmers is inappropriate. Therefore, it becomes a necessity to identify appropriate phosphorus rate for specific soil types, cultivars, regions and locations. Thus, the present research was conducted to determine optimum phosphorus (P) fertilizer rate for optimum growth and fruit yield of tomato in Ilorin, a location in the Southern Guinea savannah zone of Nigeria.

\section{MATERIALS AND METHODS}

Experimental site: The experiment was conducted at the University of Ilorin Teaching and Research Farm. The University is located between Latitude $8^{\circ} 29^{\prime} \mathrm{E} \&$ $8^{\circ} 30^{\prime} \mathrm{E} \mathrm{N}$ and Longitude $\left.4^{\circ} 30^{\prime} \mathrm{E} \& 4^{\circ} 32^{\prime} \mathrm{E}\right)$. The location is about $307 \mathrm{~m}$ above the sea level in the Southern Guinea savannah ecological zone of Nigeria.

Soil sampling, testing and field preparation: Soil samples of the experimental plot were taken using systemic sampling. The samples were taken from the top $0-15 \mathrm{~cm}$ and bulked together to get a composite sample. The composite sample was then air dried for 5 days, sieved through a $2 \mathrm{~mm}$ sieve and analysed for both physical and chemical properties (Table 1). The land used was ploughed, harrowed, and ridged. Beside the experimental plot was a nursery bed for raising tomato seedlings. The bed was located as such to ease transplanting.

Planting materials and nursery establishment: Tomato seeds of variety UC82B packed by the Premier Seeds Nigeria Limited were used in this experiment. The seeds were planted using broadcasting method to have enough number of seedling while transplanting. The bed was well irrigated before sowing. Subsequently, the bed was irrigated on a regular basis till the seedlings were ready for transplanting. Shade was provided to protect the seedlings from high insolation and heavy down pour.

Field establishment, treatments and cultural practices: Healthy and uniform seedlings were transplanted to the field when they were five weeks old. The size of the field was $3 \mathrm{~m}$ by $3 \mathrm{~m}$. Plant spacing was 60 by $120 \mathrm{~cm}$. The field was laid out in randomized complete block design with three replications. Two weeks after transplanting, five levels of $\mathrm{P}$ fertilizer $(0$, $30,60,90$ and $120 \mathrm{~kg} / \mathrm{ha})$ in form of single superphosphate (SSP) were tested on the plants. Weed control was done manually with the use of hoe. The first weeding was at 3 weeks after transplanting (WAT) while the second one was at 6WAT.

Data collection and analysis: At 4 weeks after transplanting (WAT), three representative plants were selected at the middle row of each plot and tagged for observation and data collection throughout the experimental period. Plant height measured from the base of the plant stem above the ground to the last expanded leaf tip using a tape rule. The number of branches, leaves and fruits were manually counted while leaf area was determined using graphical method (Sestak, 1971). At harvest, the fruit yield per hectare was determined at harvest. All the data collected were analysed using analysis of variance with the aid of Genstat 5.2 and significant means were separated using least significant difference (LSD) at $5 \%$ probability level.

Table 1: Physical and chemical properties of the field soil used

\begin{tabular}{ll}
\hline Parameters & Values \\
\hline $\mathrm{pH}($ water $)$ & 6.20 \\
$\mathrm{P}(\mathrm{mg} / \mathrm{kg})$ & 1.20 \\
$\mathrm{Ca}(\mathrm{Cmol} / \mathrm{kg})$ & 1.40 \\
$\mathrm{~K}(\mathrm{Cmol} / \mathrm{kg})$ & 1.80 \\
$\mathrm{Mg}(\mathrm{Cmol} / \mathrm{kg})$ & 0.90 \\
$\mathrm{Na}(\mathrm{Cmol} / \mathrm{kg})$ & 1.20 \\
$\mathrm{~N}(\mathrm{~g} / \mathrm{kg})$ & 0.05 \\
$\mathrm{Sand}(\%)$ & 83.52 \\
Silt $(\%)$ & 8.00 \\
Clay $(\%)$ & 8.48 \\
Soil textural class & Loam \\
\hline
\end{tabular}

\section{RESULTS AND DISCUSSION}

The $\mathrm{P}$ effect on plant height was different from that of the control only when the rate of application reached $90 \mathrm{~kg} / \mathrm{ha}$ single super phosphate (SSP) and it was consistent throughout the period of observation and data collection. At the last stage of data collection, the tallest plants were still from plots treated with $90 \mathrm{~kg} / \mathrm{ha}$ SSP while the shortest plants were from plots treated with $30 \mathrm{~kg} /$ ha SSP (Figure 1). Production of the tallest plants with the application of $90 \mathrm{~kg} / \mathrm{ha}$ SSP could have resulted from increase in metabolic activities of the plant for which is the function of phosphorus nutrition. It might also be that application of $90 \mathrm{~kg} / \mathrm{ha}$ SSP aided mitotic division of the shoot apical meristem and that led to better increase in height than the other application rates. Arora et al.(1994) lent credence to this observation through finding significant 
improvement in plant height and fruit size with application of $0-90 \mathrm{~kg} / \mathrm{ha}$ phosphorus fertilizer.

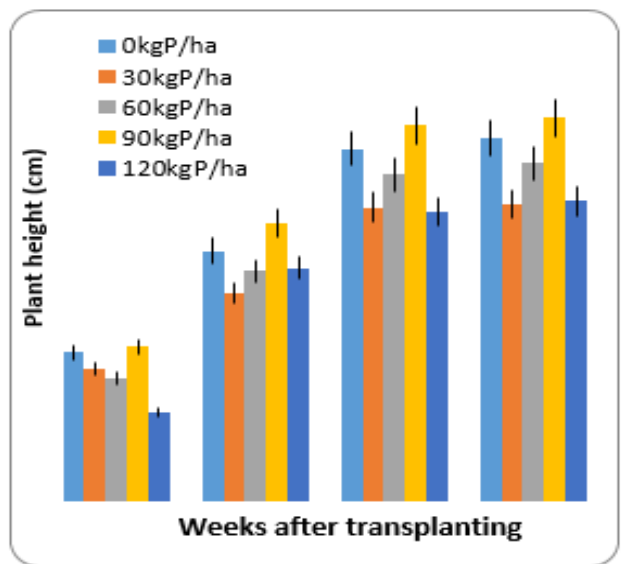

Fig 1: Effect of phosphorus fertilizer on plant height at different ages: The vertical line on each bar in the graph represents a standard error bar

There was a linear increase in the trend of leaf production from 4 th to 10 th week after transplanting. However, leaf production from the control plants was the same with that of $30 \mathrm{~kg} / \mathrm{ha}$ SSP treated plants at 10th week after transplanting. The highest number of leaves was produced by both the control and $30 \mathrm{~kg} / \mathrm{ha}$ SSP treated plants. $0 \mathrm{kgP} / \mathrm{ha}$ and $30 \mathrm{~kg} / \mathrm{ha} \mathrm{SSP}$ treated plants were $49.18 \%$ better than $120 \mathrm{~kg} /$ ha SSP treated plants (Figure 2).

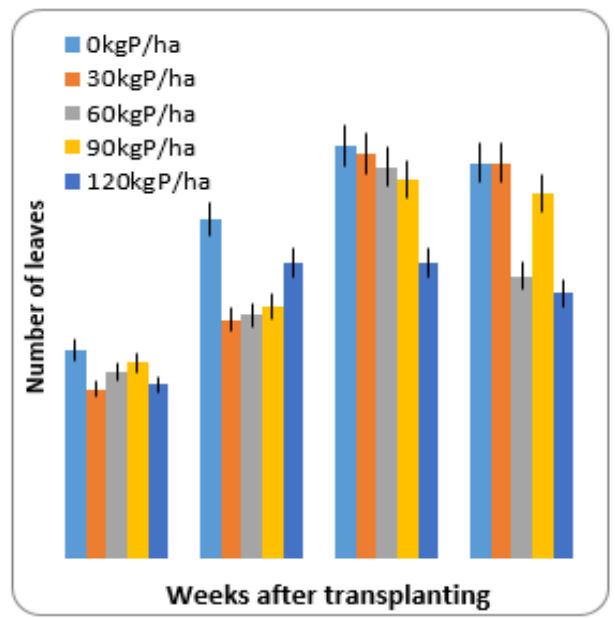

Fig 2: Effect of phosphorus fertilizer on number of leaves per plant at different ages. The vertical line on each bar in the graph represents a standard error bar.

The linear relationship of leaf production with passage of time for all the levels of $\mathrm{P}$ fertilizer application which witnessed a decline at the last stage might be the result of adversity of weather (water deficit) which hampered the release of $\mathrm{P}$ for plant use. It could equally be due to variations in plant vigour and senescence of leaf caused by low water intake by plants and high temperature. It has been established that when development is depressed by adverse factors such as water deficiency or soil temperature, growth and development might not occur (Alonso-Blanco et al., 2009). The response of branch production to $\mathrm{P}$ fertilizer was less than that of the control except for $90 \mathrm{~kg} / \mathrm{ha}$ SSP application which was finally on the par with the control. Although the branches increased as the time passed by, the response was as if no additional nutrient was added (Figure 3 ).

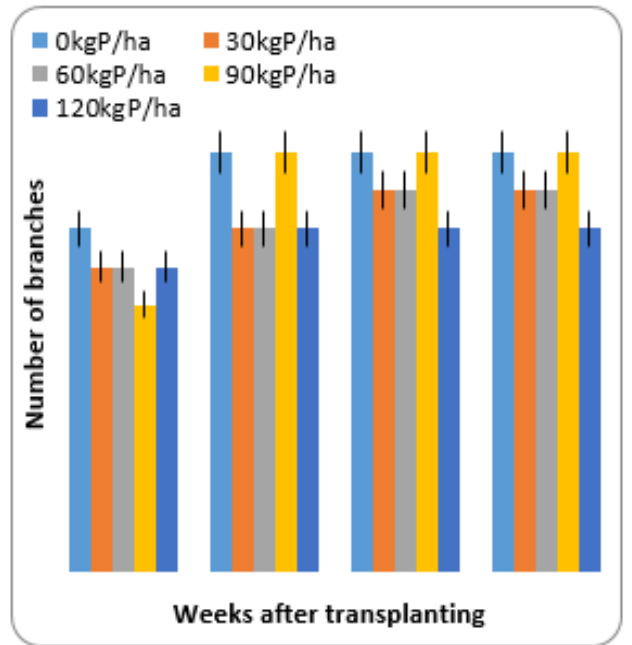

Fig 3: Effect of phosphorus fertilizer on number of branches per plant at different ages. The vertical line on each bar in the graph represents a standard error bar.

The control plots produced the highest number of branches. This could have resulted from optimum nitrogen supply of phosphorus from the soil because phosphorus is the one responsible for general vegetative growth of which branch production is a part. Despite this observation, researchers like Elmaziny et al.,1990, Naik and Srinivas (1992) as well as Bhat and Dhar (1999) upheld that increase in fruit length and number of branches were direct result of very high rate of phosphorus fertilizer application. Tomato leaf area also increased with passage of time with the least found from plants treated with $120 \mathrm{~kg} / \mathrm{ha}$ SSP. At the final stage, the largest leaf area was found in $30 \mathrm{~kg} / \mathrm{ha} \mathrm{SSP}$ treated plants while the least was from the control. All the phosphorus treatments were better than the control (Figure 4). The leaf area was partially affected by the phosphorus fertilizer application because leaf area increased with increase in fertilizer levels. This result may be attributed to beneficial effect of phosphorus on cell division and formation of carbohydrates. However, increasing rate of applied 
phosphorus fertilizer may increase production costs and result in environmental pollution.

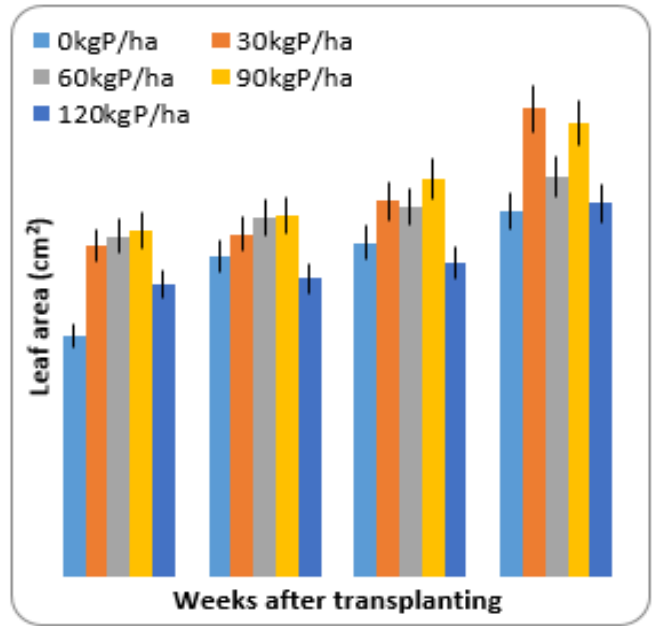

Fig 4: Effect of phosphorus fertilizer on tomato leaf area per plant $\left(\mathrm{cm}^{2}\right)$ at different ages. The vertical line on each bar in the graph represents a standard error bar.

At 10weeks after transplanting, there was a change in the trend of leaf area development which may be caused by adverse weather and edaphic condition such as high soil temperature. The causes of observed changes as well as purpling and premature senescence are associated with certain external and internal factors in the plants (Alonsco-Blanco et al., 2009). Fruit production per plant was better with application of 90 and $120 \mathrm{~kg} /$ ha SSP while the rest treatments were the same (Figure 5).

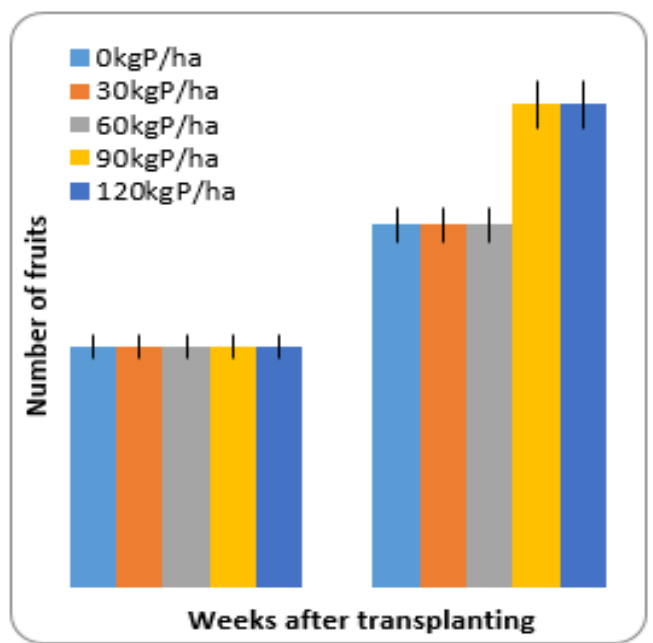

Fig 5: Effect of phosphorus fertilizer on number of fruits per plant at different ages. The vertical line on each bar in the graph represents a standard error bar.
The highest number of fruits was produced by application of $120 \mathrm{~kg} / \mathrm{ha}$ SSP while the lowest number of fruits was produced with application of $60 \mathrm{kgP} / \mathrm{ha}$. Therefore, the positive effect of phosphorus fertilizer on vegetative growth and its components previously discussed surely reflected on number of fruits produced. This implies that phosphorus supplementation could significantly improve the vegetative growth of tomatoes as well as number of fruits per plant (Moustafa et al., 2005). Fruit yield was enhanced by application of phosphorus fertilizer. $90 \mathrm{~kg} / \mathrm{ha}$ SSP application had the highest yield while the control had the lowest. Application of $90 \mathrm{~kg} / \mathrm{ha} \mathrm{SSP}$ was $66 \%$ better than the control in fruit production (Figure 6).

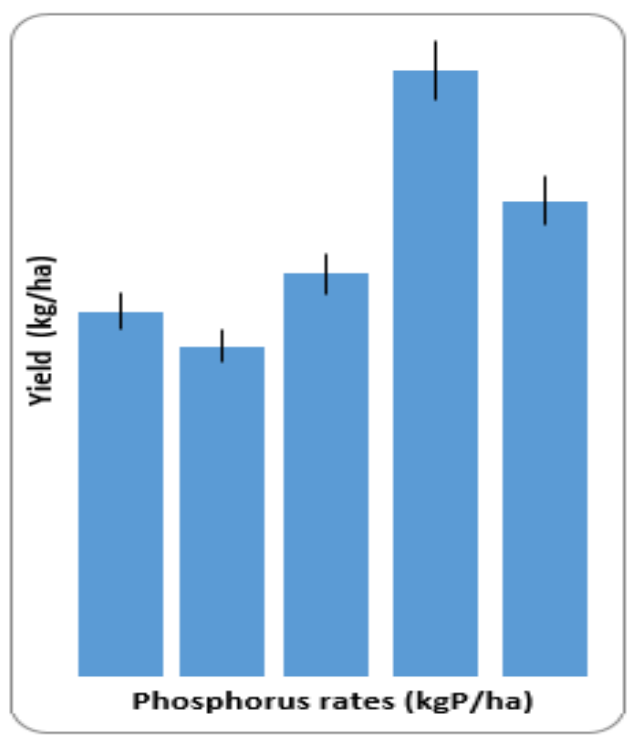

Fig 5: Effect of phosphorus fertilization on fruit yield of tomato

The highest yield per hectare was realized from application of $90 \mathrm{~kg}$ of phosphorus per hectare. So, addition of phosphorus fertilizer could result in significant increase in fresh and dry masses of tomato as it also occured in maize plants (Mehalla et al., 2004). Furthermore, phosphorus improves germination percentage, blooming, fruit setting, seed fertility and fruit yield. These might be the result of positive effect of phosphorus on plant metabolic processes which include cell division, formation, expansion and carbohydrate movement (Marschner, 1995)

Conclusion: From this work, it was found that application of $\mathrm{P}$ fertilizers (SSP) up to $90 \mathrm{~kg} / \mathrm{ha}$ increased fruit yield. Therefore, optimum fruit yield in UC82B tomato cultivar could be achieved with application of $90 \mathrm{~kg} / \mathrm{ha}$ SSP in the Southern Guinea 
savannah agro-ecological zone and places with the same climatic and edaphic conditions.

\section{REFERENCE}

Aduayi, EA; Chude, VO; Adebusuyi, BA; Olayiwola, SO (2002). Fertilizer use and management practices for crops in Nigeria (3rd Ed.).Federal Fertilizer Department, Federal Ministry of Agriculture and Rural Development, Abuja, p. 90 .

Ali, S; Khan, AZ; Mairaj, G; Arif, M; Fida, M; Bibi, S (2008). Assessment of different crop nutrient management practices for yield improvement. Austr. J. Crop Sci. 2(3):150-157.

Alonsco-Blanco, C; Aarts, MG; Bentsink, L; Keurenties, JJ; Reymond, M; Vreugdenhil, D; Koornnef, M (2009). What has natural variation taught us about plant development, physiology and adaption? Plant cell 21(7):1877-1896.

Arora, SK; kumar, N; Sharma, BR (1994). Effect of nitrogen and phosphorus fertilization on growth and yield components in okra. Haryana J. Hort sci. 20: 3-4.

Bhat, KL; Dhar, RK (1999).Effect of nitrogen and phosphorus on seed yield of okra. Vegetable Sci., 26: 89-90.

Chen, JH (2006). The combined use of chemical and organic fertilizers and/or biofertilizer for crop growth and soil fertility. International Workshop on Sustained Management of the Soil-Rhizo spehere System for Efficient Crop Production and Fertilizer Use 16-20 October, 2006.

El-maziny, MY; Hassan, MA; Farraj, MM (1990). Effect of plant density and NPK rate on Okra. Environment, 21, 995-1005.

Lambers, H; Freijsen, N; Poorter, H; Hirose, T; van der Werf, A (1990). Analysis of growth based on net assimilation rate and nitrogen productivity: their physiological background. In Causes and Consequences of Variation in Growth Rate and Productivity of Higher Plants (eds H. Lambers, M. L. Cambridge, H. Konings \& T. L. Pons), pp. 1-18. SPB Academic Publishing, The Hague, Netherlands.

Marschner, H (1995). Mineral Nutrition of Higher plants, 889pp. $2^{\text {nd }}$ ED. Academic Press, San Diego, CA.
Mehala, HL; Kirkby, EA; Shaktawat,MS( 2004). Effect of source and levels of phosphorus and FYM on yield attributes, yield and nutrient uptake of maize (Zea mays L.). Annals of Agric. Res., 25(4): 571-576.

Mokwunye, AU (1999). Food security through science. African Recovery, 44: 28-29.

Moustafa, CKE; Taehyun, N; Schofield, H; Gopinadhan, $\mathrm{P}(2005)$. Effects of phosphorus fertilizer supplementation on processing quality and functional food ingredients in tomato. Agricultural and food chemistry, 519: 742-751

Naik, LB; Srinivas, K (1992). Influence of nitrogen and phosphorus fertilization on seed crop of okra. Indian J. Agron. 37(4): 769-771

Raaimakers, D; Boot, RGA; Dijkstra, P; Pot, S; Pons, $T$ (1995). Photosynthetic rates in relation to leaf phosphorous content in pioneer vs climax tropical rain forest trees. Oecologia 120, 120125.

Schachtman, DP; Reid, RJ; Ayling, SM (1998). Phosphorus uptake by plants: from soil to cell. Plant Physiology 166, 447-453.

Sestak, Z; Catsky, J; Jarvis, PG (1971). Plant photosynthesis production. Manual of Methods. Junk Publishers, The Hague, The Netherlands.

Shaheen, AM; Abdel-Mouty, MM; Ali, AH; Rizk, FA (2007). Natural and chemical phosphorus fertilizers as it affected onion plant growth, bulb yield and some of its physical and chemical properties. Austral. J. Basic Appl. Sci. 1(4):519524.

Willcox, JK; Catignani, GL; Lazarus, S (2003). Tomatoes and cardiovascular health. Critical Reviews in Food Science and Nutrition. 43(1): 1-18.

Periago, MJ; Garc'ra-Alonso, JK; Jacob, K (2009). Bioactive compounds, folates and antioxidant properties of tomatoes (Lycopersicum esculentum) during vine ripening, Inter. J. Food Sci. Nutrition. 60 (8):694-708. 